\title{
Environmental Consideration For Physical Housing Improvement In Bukit Kencana Jaya Semarang
}

\author{
Landung Esariti ${ }^{*}, M$ D Putri \\ Department of Urban and Regional Planning, Faculty of Engineering, Diponegoro University, \\ Semarang, Indonesia
}

\begin{abstract}
So far, economic factors dominate the reasons for doing physical renovation activities of the houses. This means that the more stable the condition of the household economy, the physical improvement activities will be more likely to be conducted. This study investigates how the physical changes of the house are carried out at each stage of the family life cycle in Bukit Kencana Jaya Semarang. The four stages in family life cycle are single families, families without children, families with children and elderly families. Furthermore, this study also analyse what are the environmental considerations that influence the physical changes made. The method used is survey research, with the distribution of questionnaires to 60 respondents in 5 different types of houses. This research confirms that house physical change activities are household sustainability strategies to improve quality of life and achieve well-being. Proximity to environment facilities and location attachment to neighbourhood became the main environmental considerations findings. This research output supports the objective of Sustainable Development Goals number 3 about health and well- being, and Sustainable Development Goals number 11 on sustainable communities.
\end{abstract}

Keywords: housing physical improvement; family life cycle; environment sustainability

\section{Introduction}

The implementation of Indonesian housing is regulated in Government Regulation Number 14 of 2016 which explains that housing and settlement management includes the activities of planning, construction, utilization and control activities, institutional development, funding, and financing systems, whose the role of relevant institutions are coordinated and integrated within community. In fact, the first home purchase of Indonesian households is influenced by the funds stability owned by family. In a house selection, Karsten [1] suggested that people must consider another factor besides the economy, namely the

* Corresponding author: landungesariti@lecturer.undip.ac.id 
demographic factor ,i.e. the family life cycle. The family life cycle were originated by Clark \& Onaka [2], Duvall (1971) in Mulyati et al. [3] which describing the stages and growth of family members within households. Explained further, it consists of four stages of household development, namely single families, young families without children, families with children and elderly families. According to Clark \& Onaka [2], the stages of the family life cycle are closely related to household composition, marital status, and household size. Supporting this statement, in general, the physical growth conditions of houses in Indonesia, which are carried out through renovation activities, show that these activities are an improvement response made to household size increase. Priemus [4] has mentioned in a number of researches related to housing policy, that the development of houses shows the sociological improvement process. Improving the physical condition of the house, will indirectly support the quality of life and establish family well being.

This article analyzes the extent to which environmental factors considerations determine the type of physical improvement undertaken at Bukit Kencana Jaya Housing Area, Semarang. The hypothesis is that environmental factors are also a priority in the consideration of house selection and are also the main attraction for carrying out physical housing improvement activities carried out at each stage of the family life cycle. Physical improvement activities are associated with improving the quality of life which is reflected in subjective well being. In the elderly family group, the main consideration is the transportation and comfort of the environment around the house Cvitkovich \& Wister [5]. Added by Filion et al. [8] that the improvement of the elderly group to environmental conditions determine the comfort and closeness to neighbors interaction. Whereas for families with children, the main consideration is related to the availability of children's playgrounds, the size of the house, air ventilation and lighting circulation inside houses [7]. Chaudhuri [8] pointed out that the location close to the school was also an important factor in families with children. This shows that environmental accessibility is also very important, as stated by Kellekci \& Berköz [9] that maintenance of the environment and the density of building and traffic are the two factors revealing the opinions of housing area users about the criteria of their housing environmental features. In conclusion, the physical improvement activities of the home which are carried out by each family life cycle are efforts to maintain the sustainability of family life Olotuah [10], namely by changing the layout of the house building Xue [11] which is adjusted with consideration of environmental factors. Therefore, this paper investigates which environmental considerations influences housing physical improvement in Bukit Kencana Jaya Semarang.

The research location is in Bukit Kencana Jaya Housing Area, Meteseh, Tembalang District, Semarang City. This is based on consideration of the tendency of housing development in Semarang City towards suburban areas. Referencing from Semarang City Spatial Plan for 2011-2031, Tembalang District is managed as medium to high density housing. Another reason for choosing research locations in the Bukit Kencana Jaya Semarang Housing Area because it has been inhabited since 1987, therefore changes in the physical condition of the house in relation to the development of the family life cycle could be investigated.

\section{Methods}

This study uses descriptive statistical analysis techniques on environmental considerations. Based on literature review conducted previously, it is recommended that home environmental factors to be analyzed are home density, availability of environmental parks or open areas, availability of worship facilities, availability of educational facilities, availability of health facilities, availability of security facilities and availability of retailbusiness facilities. 
The questionnaire was distributed to 60 respondent, which were scattered on the types of houses found in research location, i.e. type $21(44 \%)$, type $22(25 \%)$, type $36(3 \%)$, type $42(10 \%)$, and type $45(18 \%)$ to see the trend of changes made. The classification of respondents based on family life cycle are single (9\%), family with children (73\%), family without children (5\%), and elderly family (13\%). Observations were also conducted to notify changes in the physical condition of the house at each stage of the family in order to know the characteristics of the renovation of the house.

\section{Results and Discussion}

\subsection{Characteristic of Physical Housing Improvement based on Family Life Cycle}

This research confirms that the majority of households in Indonesia buy small size houses, and make changes to the physical condition of the house to accommodate the increased need for space in line with increasing household size. Based on findings in the field, it is known that $88.3 \%$ of the total respondents did change the physical condition of the house, while the rest do nothing. These renovation activities were conducted by families with and without children, and elderly families.

Changes in the physical condition of the house include adding more spaces / rooms, increasing the number of building floors, and changing the function of the room. This phenomenon explains several things. First, the single group did not make changes to the physical condition of the house, because of non-financial consideration Andersen [12]. In another words, their houses is sufficient enough and accomodates their interest of easy and practical operational maintenance. Second, new families, with and without children, tend to make changes to kitchen renovations and use of space as a place of business. Kitchen renovations are carried out as activities in the service room increase. Furthermore, the addition of utilization as a place of business aims to increase family income, by renting the front yard of the house or making a home-based businessat terraces Njo et al. [13]. Third, families with children make changes to the more varied physical conditions of the house, namely kitchen renovations, addition of the number of bedrooms, increase in the number of bathrooms, and changes in siteplans. This is due to the significant increase in household size as space requirements for various activities encourage the efficiency of space in the house owned. Fourth, the elderly family changes the physical condition of the house in the form of changes in spatial function. This is because elderly families tend to occupy large houses of type 42 and type 45 . This finding is contrary to the statement of Painter \& Lee [14] where elderly families more probable to move homes to smaller sizes to avoid responsibility for operational maintenance. However, field findings show that elderly families remain in existing homes to accommodate space required when children and grandchildren come to visit.

It can be concluded that, the tendency for changes is majorly conducted in type 21 and type 22 houses. This evidences show that initial home buying due to financial sufficiency. Later on when family life cycle increases, the physical housing improvement were conducted to responds for more stability and bigger space requirements. Details of original siteplan for type 21 and type 22 and general physical changes conducted can be seen in Figure 1. 


\subsection{Environmental Consideration in Relation to Physical Housing Improvement}

The tendency of changes in the physical condition of houses in the Bukit Kencana Jaya Semarang Housing Area is carried out in the open space of the house, i.e. in the backyard and front garden (Figure 3b). The typology of changes are the addition of the number of rooms to accommodate the needs of family members, the incorporation of room functions such as combining living room and family room functions for the efficiency of space owned; and changing the function of the terrace into a business space $[3,15,16]$. In addition, an alternative change in the physical condition of the house could be conducted by increasing the number of building floors. Normally, this is conducted by separating function between floors. 1st floor is for public and semi public use, whereas 2nd floor is for more private activities. Another possibility that exist is by mergering of two type 21 houses into one building.

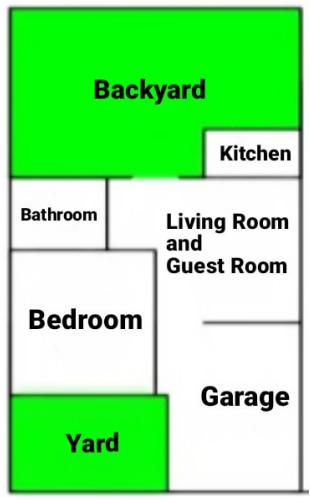

(a) First Sketch of Type 21 and 22

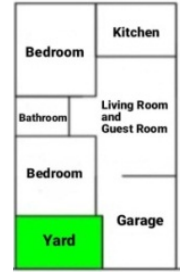

(b) First Alternative of Sketch Modification

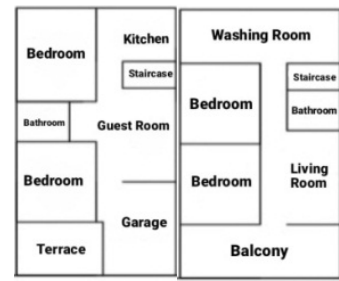

First Floor

Second Floor

(c) Second Alternative of Sketch Modification

Fig. 1. Change of House Plans For Type 21 and Type 22

Bradley [7] emphasized that children well being is related to the condition inside the houses and the environment. Spacious place to play, proximity to school and environmental health in the home greatly affect children growth and development [17]. This was confirmed by Bramley \& Power [18] who recommended that environmental factors are also important and related to social sustainability. Two key dimensions of social sustainability are the social equity and sustainability of community. In addition, outcome patterns relate to access to services and facilities. This suggests trade-offs within the social dimensions of sustainability, as well as between the social, environmental, and economic dimensions.

The results show that the satisfaction of living was determined by environmental factors in the form of accessibility [9]. Accessibility also has an important influence on the level of user satisfaction in housing and environmental quality. In order of importance, the factor groups of this criterion are centrality and accessibility to educational institutions, open areas, health institutions and public transportation, respectively. Kellekci \& Berköz [9] further added that according to the level of importance, the maintenance of the environment and the density of building and traffic are the two factors revealing the opinions of housing area users about the criteria of their housing environmental features. A well cared for housing environment creates a positive image, decreasing users' complaints about the 
housing area and increasing environmental quality. As a result, housing and environmental quality satisfaction is improved.

Adopting from the Housing Improvement Project in Sweden, the most important environmental factors of residence are: accessibility, usability, and activity. Fänge \& Iwarsson [19]. Findings are consistent with studies showing that certain attributes of the built environment around homes are positively related to physical activity, but in this case only when the outcome was location-based [20]. This also means that proximity to environment infrastructure is important. As stated previously, family with children have locational attacthed to school and leisure educational facilities such as playground, community open spaces, library and parks [21].

Furthermore, families with children tend to consider the distance to work. Residents prefer to use private vehicles to and from house to work or other mobilities. It is because in Bukit Kencana Jaya links to financial aspects and limited public transportation options existed.Surprisingly, results confirm that, the elderly family group tends to consider the distance to school, especially kindergarten and elementary school. Since the elderly group has dependencies with these two facilities such as opening a daycare center and offering shuttle services for children schooling. It recommends the existence of production motives associated with increasing family income, for example when elderly families take advantage of proximity to school facilities, especially kindergartens and primary schools as income earning opportunities [22]. In addition, income opportunities can also be made by opening child care services. Research in transportation, urban design, and planning has examined associations between physical environment variables and individuals' walking and cycling for transport [23]. This applies to all groups of stages of the family life cycle, especially elderly families, where health fulfillment is the main determinant. The walking distance to worship facilities such as mosques and churches suggested that elderly families has locational attachment to their housing environment.

\section{Conclusion}

This study recommends that changes in home conditions depend on the dynamics of family development, which is indicated by differences in characteristics at the four stages of the family life cycle. The most influential environmental consideration factor is the proximity of the location to environmental facilities such as schools, health and worship. A solid relationship between neighbours fosters location dependency, which results in each family preference to renovate a house and survive in an existing home, rather than moving to a house that is more appropriate to the level of its life cycle. This confirms the sustainability strategy in improving the quality of family life. It also evidences that the availability of adequate environmental facilities will support family well-being to continue to perform as healthy and productive community.

\section{Acknowledgement}

This research was financially supported by The Faculty of Engineering, Diponegoro University, Indonesia through Strategic Research Grant 2020. 


\section{References}

1. Karsten, L. Housing as a way of life: Towards an understanding of middle-class families' preference for an urban residential location. Hous. Stud. 22, 83-98 (2007)

2. Clark, W. A. V. \& Onaka, J. L. Life Cycle and Housing Adjustment as Explanations of Residential Mobility. Urban Stud. 20, 47-57 (1983)

3. Mulyati, M., Laras Nugraheni, P. \& Martiastuti, K. Analysis of Family Typology Based on Family Development Stage. KnE Soc. Sci. 3, 266 (2019)

4. Priemus, H. Housing As a Social Adaptation Process. Environment and Behavior vol. 18 31-52 (1986)

5. Cvitkovich, Y. \& Wister, A. The importance of transportation and prioritization of environmental needs to sustain well-being among older adults. Environ. Behav. 33, 809-829 (2001)

6. Filion, P., Wister, A. \& Coblentz, E. J. Subjective dimensions of environmental adaptation among the elderly: A challenge to models of housing policy. J. Hous. Elderly 10, 3-32 (1993)

7. Bradley, R. H. Children's Housing and Physical Environments. Handb. Child Psychol. Dev. Sci. 1-38 (2015) doi:10.1002/9781118963418.childpsy412

8. Chaudhuri, N. Interventions to improve children's health by improving the housing environment. Rev. Environ. Health 19, 197-222 (2004)

9. Kellekci, Ö. L. \& Berköz, L. Mass housing: User satisfaction in housing and its environment in Istanbul, Turkey. Eur. J. Hous. Policy 6, 77-99 (2006)

10. Olotuah, A. O. Housing Development and Environmental Degeneration in Nigeria. Built Hum. Environ. Rev. 3, 42-48 (2010)

11. Xue, J. Potentials for decoupling housing-related environmental impacts from economic growth. Environ. Dev. 4, 18-35 (2012)

12. Andersen, H. S. Motives for tenure choice during the life cycle: The importance of non-economic factors and other housing preferences. Housing, Theory Soc. 28, 183207 (2011)

13. Njo, A., I. Made, N. \& Irwanto, A. Dual process of dual motives in real estate market Indonesia. Int. J. Hous. Mark. Anal. 12, 25-42 (2019)

14. Painter, G. \& Lee, K. O. Housing tenure transitions of older households: Life cycle, demographic, and familial factors. Reg. Sci. Urban Econ. 39, 749-760 (2009).

15. McLeod, P. B. \& Ellis, J. R. Housing Consumption Over the Family Life Cycle: an Empirical Analysis. Urban Stud. 19, 177-185 (1982)

16. Morrow-Jones, H. A. \& Wenning, M. V. The housing ladder, the housing life-cycle and the housing life-course: Upward and downward movement among repeat homebuyers in a US metropolitan housing market. Urban Stud. 42, 1739-1754 (2005)

17. Love, D. A. The effects of marital status and children on savings and portfolio choice. Rev. Financ. Stud. 23, 385-432 (2010)

18. Bramley, G. \& Power, S. Urban form and social sustainability: The role of density and housing type. Environ. Plan. B Plan. Des. 36, 30-48 (2009)

19. Fänge, A. \& Iwarsson, S. Challenges in the development of strategies for housing adaptation evaluations. Scand. J. Occup. Ther. 14, 140-149 (2007)

20. Troped, P. J., Wilson, J. S., Matthews, C. E., Cromley, E. K. \& Melly, S. J. The Built Environment and Location-Based Physical Activity. Am. J. Prev. Med. 38, 429-438 
(2010).

21. Tan, T. H. Meeting first-time buyers' housing needs and preferences in greater Kuala Lumpur. Cities 29, 389-396 (2012)

22. Rahmadaniyati, D., Faqih, M. \& Hayati, A. Housing Preference for Low-Income People in Indonesia. 1-12 (2005)

23. Saelens, B. E., Sallis, J. F. \& Frank, L. D. Environmental correlates of walking and cycling: Findings from the transportation, urban design, and planning literatures. Ann. Behav. Med. 25, 80-91 (2003) 